\title{
Hubungan Pelaksanaan Peran Keluarga dengan Kejadian Stunting pada Balita di Kecamatan Arjasa, Jember
}

\section{(Correlation between Implementation of Family Role and Stunting in Toodler in Subdistricts of Arjasa, Jember)}

\author{
Umari Hasniah Rahmawati, Latifa Aini S., Hanny Rasni \\ Program Studi IImu Keperawatan Fakultas Keperawatan Universitas Jember \\ Jl. Kalimantan No.37 Kampus Tegal Boto Jember. Telp/Fax. (0331) 323450 \\ e-mail : latifa_as.psik@unej.ac.id
}

\begin{abstract}
A family has an important role to meet the nutritional intake of toddlers since a family has a full decision to nurture and take care of the toddlers. However, the case of stunting in Jember Regency still has a higher case compared to other regencies. The objective of this research was to analyze the relationship between the implementation of family role and the case of stunting in toddlers in Arjasa Subdistrict, Jember regency. The research also used a cross sectional research design with cluster random sampling technique. The data collection was conducted by providing a FAD (Family Assessment Device) questionnaire used to identify the family roles, while the height was measured by length board and microtoise. The chi-square test was employed to analyze between the variables of family role and stunting case. According to the analysis result of 117 respondents, there were $7.7 \%, 99 \%$ and $7.7 \%$ for each category of good, moderate and less in the family role, whereas for the stunting case, there were $76.1 \%$ having stunting and $23.9 \%$ not stunting. The findings of this research indicated that there was a relationship between the implementation of family role and the stunting case $\left(x^{2}=9.78 ; p\right.$-value $\left.=0.002\right)$, in which the implementation of family role in the good category had 7.81 times for a chance of stunting (OR $=7.81 ; 95 \% \mathrm{Cl}=1.81-33.762)$. at last, this research showed the importance of improving the family role by involving the family to meet the daily nutritional intake of toddlers so as the stunting case can diminish.
\end{abstract}

Keywords: Family role, Stunting, Toddlers

\begin{abstract}
Abstrak
Keluarga memiliki peran yang penting dalam pemenuhan asupan gizi anak usia balita karena pada usia balita keluarga memiliki keputusan penuh dalam merawat dan mengasuh balita. Namun kejadian stunting di Kabupaten Jember masih memiliki angka kejadian stunting yang lebih tinggi dibanding kabupaten lain. Penelitian ini memiliki tujuan untuk menganalisa hubungan pelaksanaan peran keluarga dengan kejadian stunting pada balita di Kecamatan Arjasa Kabupaten Jember. Penelitian ini menggunakan desain penelitian cross sectional dengan teknik pengambilan sampel cluster random sampling. Pengumpulan data dilakukan dengan memberikan kuesioner FAD (Family Assessment Device) yang digunakan untuk mengidentifikasi peran keluarga, sedangkan untuk tinggi badan diukur dengan length board dan microtoise. Uji chi-square digunakan untuk menganalisis antara variabel peran keluarga dan variabel kejadian stunting. Berdasarkkan hasil analisis dari 117 responden terdapat peran keluarga dalam kategori baik $7,7 \%$, sedang $99 \%$ dan kurang $7,7 \%$, sedangkan untuk kejadian stunting terdapat $76,1 \%$ mengalami stunting dan $23,9 \%$ tidak mengalami stunting. Hasil penelitian menunjukan terdapat hubungan antara pelaksanaan peran keluarga dan kejadian stunting $\left(x^{2}=9,78 ; p\right.$-value $\left.=0,002\right)$, dimana pelaksanaan peran keluarga dalam kategori baik memiliki peluang 7,81 kali mengalami stunting $(\mathrm{OR}=7,81 ; 95 \% \mathrm{Cl}=1,81-33,762)$. Penelitian ini menujukkan pentingnya meningkatkan peran keluarga dengan melibatkan keluarga dalam pemenuhan kebutuhan asupan gizi pada balita sehari-hari agar kejadian stunting dapat berkurang.
\end{abstract}

Kata kunci: Peran Keluarqa, Stunting, Balita 


\section{Pendahuluan}

Stunting merupakan salah satu dari permasalahan status gizi yang ditinjau dari tinggi badan yang lebih pendek dibanding orang lain yang seusia [1]. Stunting pada tahun 2016 ditingkat dunia mencapai 22,9\% (154,8 juta) balita dimana hal tersebut terjadi akibat berbagai faktor terkait pada 1000 hari pertama setelah konsepsi [2].

Menurut Global Nutrition Report tahun 2014 menyebutkan dari 117 negara bahwa Indonesia termasuk dalam 17 negara yang memiliki tiga masalah gizi pada balita yaitu stunting $(37,2 \%)$, wasting $(12,1 \%)$ dan overweight $(11,9 \%)$ [3]. Hasil Riset Kesehatan Dasar tahun 2013 menyatakan bahwa menurunnya angka kemiskinan di Indonesia tidak mempengaruhi secara signifikan permasalahan status gizi yang masih cukup tinggi dengan angka nasional $37,2 \%$ terdiri $18 \%$ sangat pendek dan $19,2 \%$ pendek [4]. Prevalensi stunting di Jawa Timur pada tahun 2016 menunjukan angka $26,1 \%$ dengan berada sedikit dibawah angka stunting nasional yaitu 27,5\% [5]. Berdasarkan hasil survei PSG pada tahun 2016 Kabupaten Jember memiliki prevalensi stunting sebesar $39,2 \%$, Sumenep $32,5 \%$, dan Bangkalan $32,1 \%$ [6]. Prevalensi balita di Kecamatan Arjasa terdapat 2673, dengan sebagian besar balita memiliki status gizi stunting $62,5 \%$ dari jumlah populasi 2673 balita [7].

Resiko terjadinya stunting meningkat pada anak yang tinggal bersama keluarga dengan orangtua tunggal dibandingkan dengan anak yang tinggal di keluarga inti atau keluaga besar dengan orangtua lengkap [8]. Hasil penelitian tentang hubungan struktur peran keluarga dengan stunting anak usia dua sampai lima tahun menunjukan bahwa kejadian stunting $10 \%$ lebih tinggi pada anak yang tinggal dengan keluarga inti dan 30\% lebih tinggi pada anak yang tinggal dengan keluarga besar [9]. Stunting terjadi lebih sering pada anak yang tinggal di keluagra besar dibandingkan anak yang tinggal di keluarga inti dengan perbandingan $3: 1$. Permasalahan stunting perlu dilakukan penelitian terutama dari segi keluarga, karena permasalahan tersebut dapat merusak perkembangan dan berdampak negatif bagi kesehatan dalam jangka waktu lama seperti rentan terhadap penyakit [10].

Tubuh pendek atau stunting pada masa balita disebabkan oleh kurangnya gizi kronis atau gizi kurang yang mengakibatkan kegagalan pertumbuhan serta digunakannya sebagai indikator dalam jangka panjang [11]. Secara tidak langsung selain tenaga kesehatan keluarga juga berpengaruh pada status gizi balita, terutama peran ibu sejak masa sebelum kehamilan hingga setelah melahirkan. Bedasarkan penelitian Car dan Spinger pengaruh yang paling kuat pada kesehatan yaitu keluarga, karena keluarga berperan sebagai penyedia sumber daya ekonomi, sosial dan psikologis, ketegangan yang dapat menjadi pelindung ataupun ancaman dari kesehatan anggota keluarga [12].

Pemerintah telah mengupayakan mengatasi permasalahan status gizi di Indonesia melalui program Indonesia sehat dengan pendekatan keluarga dan keluarga sadar gizi. Program Indonesia Sehat memiliki sasaran yaitu derajat kesehatan dan status gizi masyarakat dengan meningkatkan kesehatan dan pemberdayaan masyarakat yang didukung perlindungan finansial dan pelayanan kesehatan yang pemerataan [13]. Program pemerintah lainnya keluarga sadar gizi, yaitu keluarga yang tidak hanya mengenal tetapi juga dapat mencegah serta mengatasi masalah gizi yang dialami oleh setiap anggota keluarganya [14].

Upaya penanggulangan masalah status gizi yang memiliki peranan penting yaitu individu, keluarga, dan pelayanan kesehatan [10]. Berjalannya pelayanan kesehatan dipengaruhi oleh tenaga kesehatan salah satunya perawat. Perawat memiliki peran dalam meningkatkan status gizi balita yaitu dengan upaya promotif dan preventif [15]. Pencegahan masalah gizi buruk yang telah dilakukan perawat meliputi proses asuhan keperawatan (penimbangan, pengukuran, dan pemantauan seacara rutin), pendidikan kesesahatan dalam konseling ataupun penyuluhan, bekerjasama dengan tenaga kesehatan lain terutama ahli gizi, berkoodinasi terkait rencana pelaksanaan kegiatan, berdiskusi untuk memecahkan permasalah status gizi, melakukan pendekatan dan memberikan pemahaman terkait gizi yang penting bagi kesehatan [15]. Namun apabila ditinjau dari prevalensi pemasalahan status gizi pada balita masih belum teratasi sehingga peneliti tertarik untuk meneliti apakah terdapat hubungan pelaksanaan peran keluarga dengan status gizi pada balita yang memiliki risiko stunting.

\section{Metode Penelitian}

Penelitian ini memiliki jenis korelasi dengan menggunakan desain observasional melalui pendekatan cross sectional. Variabel yang diukur dalam penelitian ini yaitu variabel independen (pelaksaaan peran keluarga) dan 
variabel dependen (kejadian stunting). Sampel pada penelitian yaitu sebanyak 117 responden di Kecamatan Arjasa Kabupaten Jember dengan teknik pengambilan cluster random sampling. Instrumen penelitian yang digunakan yaitu kuesioner FAD (Family Assessment Device) dengan subscale peran untuk mengukur pelaksaan peran keluarga, sedangkan untuk mengukur tinggi badan menggunakan length board untuk responden usia $>12$ bulan sampai $\leq 24$ bulan dan microtoice untuk responden usia $>24$ bulan sampai $\leq 60$ bulan. Analisis data untuk mengetahui hubungan antara variabel digunakan uji chi-square.

\section{Hasil}

Hasil penelitian berupa analisis univariat dan bivariat yang disajikan dalam bentuk tabel dan narasi. Pembahasan dalam penelitian ini disajikan dalam bentuk narasi berdasarkan hasil penelitian.

\section{Karakteristik Responden}

Tabel 1 Distribusi Karakteristik Responden di Kecamatan Arjasa Kabupaten Jember (Januari 2019; n=117)

\begin{tabular}{lr}
\hline \multicolumn{1}{c}{ Karakteristik Responden } & $\mathbf{n ~ ( \% )}$ \\
\hline Usia anak & 36,00 \\
a. Median & $12-60$ \\
b. Min-Maks & \\
\hline Tinggi badan anak & 83,94 \\
a. Mean & 10,42 \\
b. Standar Deviasi & \\
\hline Bentuk keluarga & $66(56,4 \%)$ \\
a. Keluarga inti & $47(40,2 \%)$ \\
b. Keluarga besar & $4(3,4 \%)$ \\
c. Keluarga bercerai & \\
\hline Pendidikan & $11(9,4 \%)$ \\
a. Tidak Sekolah & $46(39,3 \%)$ \\
b. SD & $32(27,4 \%)$ \\
c. SMP & $27(23,1 \%)$ \\
d. SMA & $1(0,9 \%)$ \\
e. PT & \\
\hline Status Bekerja & \\
a. Tidak Bekerja & $82(70,1 \%)$ \\
b. Bekerja & $35(29,9 \%)$ \\
\hline Pendapatan keluarga & \\
a. < Rp.2.170.917,00 & $103(88,0 \%)$ \\
b. $>$ Rp.2.170.917,00 & $14(12,0 \%)$ \\
\hline Jumlah anak dalam keluarga & $48(41,0 \%)$ \\
a. <2 anak & $69(59,0 \%)$ \\
b. >2 anak & $59(50,4 \%)$ \\
\hline Jenis kelamin anak & $58(49,6 \%)$ \\
a. Laki-laki & \\
b. Perempuan & \\
\hline
\end{tabular}

Tabel 1 menunjukkan usia anak dalam rentang 12-60 bulan di Kecamatan Arjasa dengan nilai median dari usia yaitu 36,00 .
Rentang dalam usia balita memiliki tinggi badan anak dengan rata-rata 83,94 dan standar deviasi 10,42. Anak usia balita di Kecamatan Arjasa memiliki bentuk keluarga inti sebanyak 66 keluarga $(56,4 \%)$ dengan tingkat pendidikan keluarga mayoritas sekolah dasar 46 keluarga $(39,3 \%)$ dan status tidak bekerja 82 keluarga $(70,1 \%)$. Status pengasuh balita dalam keluarga yang mayoritas tidak bekerja memiliki pendapatan keluarga < Rp.2.170.917,00 sebanyak 103 keluarga $(88,0 \%)$. Pendapat keluarga yang mayoritas dibawah UMR Kabupaten Jember namun harus membiayai jumlah keluarga yang banyak yaitu jumlah anak dalam keluarga $>2$ anak sebanyak 69 keluarga $(59,0 \%)$ dengan mayoritas berjenis kelamin laki-laki 59 anak $(50,4 \%)$.

\section{Pelaksanaan Peran Keluarga}

Tabel 2 Indikator Peran Keluarga pada Balita di Kecamatan Arjasa Kabupaten Jember (Januari $2019 ; n=117$ )

\begin{tabular}{|c|c|c|c|}
\hline Indikator & Mean & Median & $\begin{array}{l}\text { Min- } \\
\text { Maks }\end{array}$ \\
\hline \multicolumn{4}{|l|}{ Peran Formal } \\
\hline $\begin{array}{l}\text { a. Ketika kami meminta } \\
\text { anggota keluarga yang } \\
\text { lain untuk mengerjakan }\end{array}$ & 3,00 & 3,00 & $1-4$ \\
\hline \multicolumn{4}{|l|}{$\begin{array}{l}\text { sesuatu, hasilnya } \\
\text { dengan } \\
\text { inginkan. }\end{array}$} \\
\hline $\begin{array}{l}\text { b. Setiap anggota keluarga } \\
\text { mempunyai tugas dan } \\
\text { tanggung jawab masing- }\end{array}$ & 2,93 & 3,00 & $1-4$ \\
\hline \multicolumn{4}{|l|}{$\begin{array}{l}\text { masing dalam hal } \\
\text { pekerjaan rumah. }\end{array}$} \\
\hline $\begin{array}{l}\text { c. Tugas pekerjaan rumah } \\
\text { dibagi secara adil dan } \\
\text { merata kepada semua } \\
\text { anggota keluarga }\end{array}$ & 2,83 & 3,00 & $1-4$ \\
\hline 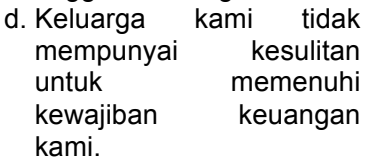 & 2,66 & 3,00 & $1-4$ \\
\hline $\begin{array}{l}\text { e. Kami selalu ingat tentang } \\
\text { apa yang menjadi tugas } \\
\text { dan tanggung jawab } \\
\text { pekerjaan rumah kami }\end{array}$ & 3,04 & 3,00 & $1-4$ \\
\hline $\begin{array}{l}\text { f. Kami merasa puas } \\
\text { dengan pembagian tugas } \\
\text { pekerjaan rumah yang } \\
\text { telah diberikan kepada } \\
\text { kami. }\end{array}$ & 3,00 & 3,00 & $1-4$ \\
\hline Total & 2,82 & 3,00 & $1-4$ \\
\hline \multicolumn{4}{|l|}{ Peran Informal } \\
\hline \multicolumn{4}{|l|}{\begin{tabular}{ccr} 
a. Keluarga kami memiliki & \multicolumn{1}{c}{ manyak waktu untuk } \\
banyak & tentang \\
mendiskusikan & hobi/kegemaran masing- \\
masing anggota keluarga
\end{tabular}} \\
\hline $\begin{array}{l}\text { b. Kami mendiskusikan } \\
\text { tentang pembagian tugas } \\
\text { dan tanggung jawab } \\
\text { masing-masing anggota }\end{array}$ & 2,81 & 3,00 & $1-4$ \\
\hline $\begin{array}{l}\text { keluarga dalam hal } \\
\text { pekerjaan rumah }\end{array}$ & & & \\
\hline Total & 2,68 & 3,00 & $1-4$ \\
\hline
\end{tabular}


Tabel 2 menununjukkan nilai rata-rata tertinggi pada pertanyaan nomor 7 dengan nilai median 3,00 , nilai minimal 1 dan nilai maksimal 4. Indikator peran formal nilai rerata tertinggi sebesar 2,826 dengan nilai minimal 1,5 dan nilai maksimal 3,7. Indikator peran informal memiliki nilai rerata terendah sebesar 2,688 dengan nilai minimal 1,0 dan maksimal 4,0 .

Tabel 3 Distribusi Peran Keluarga pada Balita di Kecamatan Arjasa Kabupaten Jember (Januari 2019; $n=117$ )

\begin{tabular}{lr}
\hline Variabel & $\mathbf{n}(\mathbf{\%})$ \\
\hline 1. Peran Keluarga & $9(7,7 \%)$ \\
a. Baik & $99(84,6 \%)$ \\
b. Sedang & $9(7,7 \%)$ \\
c. Kurang & \\
\hline Total & $117(100 \%)$ \\
\hline
\end{tabular}

Tabel 3 menunjukkan pelaksanaan peran keluarga di Kecamatan Arjasa Kabupaten Jember lebih banyak dalam kategori sedang sebanyak 99 keluarga $(84,6 \%)$ sedangkan sisanya memiliki peran keluarga dalam kategori baik dan kurang.

\section{Kejadian Stunting}

Tabel 4 Kejadian stunting pada balita di Kecamatan Arjasa Kabupaten Jember (Januari 2019; n=117)

\begin{tabular}{lr}
\hline \multicolumn{2}{c}{ Variabel } \\
\hline 1. Z-Score & n (\%) \\
a. Mean & $-2,87$ \\
b. Median & $-3,13$ \\
c. Min-Maks & $-6,84-1,29$ \\
2. Kejadian Stunting & $28(23,9 \%)$ \\
a. Tidak stunting & $89(76,1 \%)$ \\
b. Stunting & \\
\hline
\end{tabular}

Tabel 4 menyajikan terkait kejadian stunting di Kecamatan Arjasa Kabupaten Jember, hasil penelitian menunjukkan bahwa kejadian stunting yang lebih tinggi sebanyak 89 anak $(76,1 \%)$. Penetuan kejadian stunting berdasarkan pengukuran z-score dengan ratarata $-2,87$, median $-3,13$, nilai minimum $-6,84$ dan nilai maksimum 1,29.

Hubungan Pelaksanaan Peran Keluarga dengan Kejadian Stunting pada Balita

Tabel 5 Hubungan Pelaksanaan Peran Keluarga dengan Kejadian Stunting di Kecamatan Arjasa Kabupaten Jember (Januari 2019; $\mathrm{n}=117$ )

\begin{tabular}{|c|c|c|c|c|c|}
\hline \multirow[b]{2}{*}{$\begin{array}{c}\text { Peran } \\
\text { Keluarga }\end{array}$} & \multicolumn{2}{|c|}{ Kejadian Stunting } & \multirow{2}{*}{$\chi^{2}$} & \multirow[b]{2}{*}{ OR } & $95 \%$ \\
\hline & $\begin{array}{c}\text { Tidak } \\
\text { stunting } \\
\text { n (\%) }\end{array}$ & $\begin{array}{c}\text { Stunting } \\
\text { n (\%) }\end{array}$ & & & $\begin{array}{l}\text { min- } \\
\text { maks }\end{array}$ \\
\hline
\end{tabular}

\begin{tabular}{lrrccc}
\hline Baik & 6 & 3 & 9,78 & 7,81 & $1,81-$ \\
& $(5,1 \%)$ & $(2,6 \%)$ & $(0,002)$ & & 33,762 \\
$\begin{array}{l}\text { Sedang } \\
\text { dan }\end{array}$ & 22 & 86 & & & \\
kurang & $(18,8 \%)$ & $(73,5 \%)$ & & & \\
\hline
\end{tabular}

Tabel 5 menunjukan bahwa terdapat perbedaan antara peran keluarga dan kejadian stunting dibuktikan dengan uji Chi Square $\left(x^{2}\right.$ $=9,78 ; p$-value $=0,002)$, dapat disimpulkan terdapat hubungan antara pelaksanaan peran keluarga dengan kejadian stunting pada balita di Kecamatan Arjasa Kabupaten Jember. Balita yang memiliki keluarga dengan pelaksaan peran keluarga dalam kategori baik memiliki peluang 7,81 kali untuk mengalami kejadian stunting $(\mathrm{OR}=7,81 ; 95 \% \mathrm{Cl}=1,81$ $33,762)$.

\section{Pembahasan \\ Pelaksanaan Peran Keluarga}

Hasil penelitian menunjukkan bahwa pelaksanaan peran keluarga yang paling tinggi dalam katagori sedang dengan dua indikator yaitu peran formal dan informal. Skor pada indikator memiliki selisih yang dekat yaitu pada indikator peran formal dengan nilai rerata 2,826 dan indikator peran informal dengan nilai rerata 2,688. Peran keluarga yang mempengaruhi kejadian stunting pada anak usia balita berdasarkan bentuk keluarga. Penelitian ini ditemukan bentuk keluarga yang dimiliki responden mayoritas dengan bentuk keluarga inti. Hasil penelitian ini didukung oleh penelitian lain bahwa bentuk keluarga mempengaruhi terjadinya stunting, dimana kejadian stunting sering terjadi pada bentuk keluarga bercerai, sedangkan bentuk keluarga yang jarang terjadi stunting yaitu pada bentuk keluarga besar [9]. Bentuk keluarga besar dapat mempengaruhi kejadian stunting yang rendah karena dalam keluarga yang mengasuh anak selain orangtua juga terdapat nenek dan kakek yang membantu pemenuhan kebutuhan sehari-hari termasuk asupan makanan.

Bentuk keluarga dapat memberikan pengaruh dalam kejadian stunting yang sejalan dengan karakteristik jumlah anak dalam keluarga, karena keluarga tergolong besar atau kecil ditentukan oleh jumlah anak. Pada penelitian ini mayoritas keluarga memiliki anak lebih dari dua yang dapat mempengaruhi pemenuhan kebutuhan gizi dalam keluarga. Hal tersebut disebabkan anak pada keluarga dengan anggota keluarga yang banyak cenderung mendapat perhatian dan perawatan individu yang kurang [16]. Jumlah anak dalam keluarga ini juga akan semakin mempengaruhi kejadian stunting apabila ditinjau dari status ekonomi keluarga berdasarkan pendapatan keluarga. 
Pendapatan keluarga dapat dilihat dari terlaksananya peran orangtua terutama ayah yang bekerja. Penelitian ini sebagian besar responden memiliki pendapatan keluarga yang kurang dari UMK Kabupaten Jember yaitu sebesar 2.170.917. Pendapatan keluarga yang dapat memenuhi kebutuhan kelurga, tingkat pendapatan yang kurang maka memiliki kecenderungan pemenuhan kebutuhan gizi dengan pertimbangan harga yang lebih murah, dan menu kurang bervariasi. Pendapatan keluarga dapat mempengaruhi status gizi anak sejalan dengan hasil penelitian sebelumnya bahwa karakteristik pendapatan keluarga di pedesaan ataupun di perkotaan yang memiliki masalah ekonomi mengalami gangguan pertumbuhan, maka stunting lebih banyak terjadi pada keluarga dengan pendapatan rata-rata/bulan yang rendah [17]. Namun pendapat keluarga tidak mempengaruhi status gizi secara langsung karena pendapat keluarga merupakan media sebagai pemenuhan kebutuhan asupan gizi [17].

Distribusi karakteristik responden berdasarkan status pekerjaan keluarga yang mengasuh anak mayoritas tidak bekerja. Berdasarkan hasil penelitian lain bahwa status gizi anak yang karena ditinggal kedua orangtuanya bekerja belum tentu lebih buruk [18]. Penelitian lain juga menyatakan bahwa tidak ada hubungan antara status pekerjaan ibu dengan status gizi $(p=0,15)$, yaitu pada ibu yang tidak bekerja memiliki anak yang lebih pendek dibandingkan dengan ibu yang bekerja [19]. Memiliki peran pengasuh dan memiliki tanggungjawab untuk bekerja terutama yang bekerja diluar rumah akan meningkatkan pendapatan sebagai pemenuhan kebutuhan makan anak terutama pemenuhan gizi seimbang namun hal tersebut akan mempengaruhi asupan makanan dan pola asuh terhadap anaknya [19]. Peran pengasuh yang tidak berstatus sebagai bekerja akan memiliki banyak waktu dirumah dengan anaknya dan dapat mempengaruhi kualitas gizi anaknya. Penelitian ini menunjukkan bahwa mayoritas pengasuh berstatus tidak bekerja, namun angka kejadian stunting yang terjadi tinggi.

Berdasarkan hasil penelitian yang telah diperoleh terdapat indikator yang kurang yaitu peran informal. Menurut taksonomi diagnosa keperawatan yang sesuai dengan permasalahan terkait peran keluarga yaitu kesiapan meningkatakan hubungan dalam domain 7 hubungan peran pada kelas 3 performa peran dengan kode 00207 [20]. Berdasarkan diagnosa tersebut intervensi keperawatan yang dapat diberikan perawat pada balita untuk meningkatkan pelaksanaan peran keluarga yaitu melakukan peningkatan peran untuk meningkatkan hubungan dengan mengklarifikasi dan menunjang perilaku yang merupakan peran khusus [21]. Hal-hal yang dapat dilakukan pertama mengidentifikasi bermacam peran dalam siklus kehidupan dan peran biasanya dalam keluarga. Kedua mendukung keluarga untuk mengidentifikasi strategi-strategi positif untuk manajemen perubahan-perubahan peran. Ketiga memfasilitasi diskusi tentang adaptasi peran keluarga untuk dapat mengkompensasi peran anggota keluarga yang sakit.

\section{Kejadian Stunting}

Berdasarkan hasil penelitian menunjukan bahwa di Kecamatan Arjasa Kabupaten Jember keluarga yang memiliki anak usia balita memiliki permasalahan status gizi stunting. Hasil penelitian tersebut sejalan dengan penelitian lain yang menunjukan terdapat 55 balita $(62,5 \%)$ mengalami stunting di Kecamatan Arjasa Kabupaten Jember [7]. Pada penelitian ini dimungkinkan anak usia balita memiliki asupan gizi yang belum terpenuhi sehingga nilai $z$-score tergolong kurang (stunting)

Jumlah anak yang berjenis kelamin laki-laki dan perempuan secara keselurahan tidak jauh namun jumlah anak dengan jenis kelamin laki laki lebih banyak. Jenis kelamin balita tidak mempengaruhi kejadian stunting namun jenis kelamin laki memiliki risiko untuk sakit yang lebih tinggi dibandingkan perempuan [22]. Dimungkinkan jenis kelamin dapat mempengaruhi kesehatan balita yang juga akan mempengaruhi nafsu makannya.

Tingkat pendidikan orangtua yang tergolong baik akan memudahkan orangtua dalam memahami informasi yang diperoleh, dalam penelitian ini mayoritas tingkat pendidikan pengasuh balita yaitu sekolah dasar atau sederajat dengan jumlah kejadian stunting yang tergolong tinggi. Hal tersebut didukung penelitian lain bahwa tingkat pendidikan orangtua terutama ibu yang umumnya berperan sebagai pengasuh utama bagi anak dapat mempengaruhi status gizi anak [23]. Pengasuhan yang baik dapat mengurangi tingkat kejadian stunting, maka secara tidak langsung tingkat pengetahuan keluarga yang pengasuh balita dapat mempengaruhi kejadian stunting.

Berdasarkan hasil analisis status gizi, balita yang mengalami stunting berdasarakan indikator status gizi tinggi badan per usia balita yang dikategorikan dalam tidak stunting dan stunting Menurut UNICEF terdapat tigal hal yang menjadi faktor terjadinya permasalahan gizi pada anak yaitu pertama faktor langsung 
seperti asupan gizi yang kurang dan penyakit infeksi [10]. Kedua faktor tidak langsung tidak cukup pangan, pola asuh yang tidak memadai, dan sanitasi serta pelayanan kesehatan mendasar yang tidak memadai. Ketiga faktor mendasar krisis ekonomi, politik, dan sosial serta bencana alam, dimana faktor mendasar ini dapat memicu munculnya faktor tidak langsung [10].

Berdasarkan hasil penelitian yang telah diperoleh terdapat indikator yang kurang yaitu nilai z-score yang mayoritas menunjukkan status gizi stunting. Menurut taksonomi diagnosa keperawatan yang sesuai dengan permasalahan terkait kejadian stunting ketidakseimbangan nutrisi: kurang dari kebutuhan tubuh dalam domain 2 nutrisi pada kelas 1 makan dengan kode 00002 [20]. Berdasarkan diagnosa tersebut maka intervensi keperawatan yang dapat diberikan perawat pada balita untuk meningkatkan nilai $z$-score dengan manajemen nutrisi [21]. Halhal yang dapat dilakukan antaralain menentukan status gizi dan kemampuan klien untuk memenuhi kebutuhan gizi, menentukan jumlah kalori dan jenis nutrisi yang dibutuhkan untuk memenuhi persyaratan gizi, anjurkan terkait dengan kebutuhan makan tertentu berdasarkan perkembangan atau usia (misalnya makanan yang tinggi kalsium, vitamin, dan mineral untuk menunjang pertumbuhan balita), monitor kecenderungan terjadinya penurunan berat badan.

\section{Hubungan Pelaksanaan Peran Keluarga dengan Kejadian Stunting}

Hasil uji statistik penelitian ini menunjukan bawah terdapat hubungan antara pelaksanaan peran keluarga dengan kejadian stunting pada balita di Kecamatan Arjasa Kabupaten Jember dengan $p$-value $=0,002$ berarti penelitian menunjukan bahwa terdapat hubungan antara variabel independen dan variabel dependen. Pelaksanaan peran keluarga yang mayoritas dalam kategori sedang dan kurang dengan paling banyak balita mengalami stunting.

Struktur peran keluarga dapat mempengaruhi kejadian stunting berdasarkan bentuk keluarga [9]. Anak yang tinggal dengan keluarga inti memiliki tingkat kejadian stunting yang lebih tinggi dibandingkan dengan anak yang tinggal dengan keluarga besar dan anak yang tinggal dengan keluarga tunggal memiliki kejadian stunting yang lebih rendah dibandingkan dengan anak yang tinggal dengan keluarga besar [9]. Pada penelitian tersebut yang tinggal dengan keluarga besar memiliki tingkat kejadian stunting yang lebih rendah, hal tersebut dapat terjadi karena anak yang tinggal di keluarga besar memiliki peran keluarga tambahan dalam hal pengasuhan anak dan dapat mempengaruhi kesejahteraan dalam rumah tangga serta memiliki pengaruh besar pada proses pengambilan keputusan pada kepala keluarga dan anggota keluarga yang berjenis kelamin laki-laki lainnya. Anak yang tinggal dengan keluarga tunggal memiliki peran dalam keluarga yang tidak terpenuhi dalam keluarga.

Penelitian lain menunjukkan bahwa pendidikan orangtua dapat mempengaruhi status gizi salah satunya kejadian stunting. Hal tersebut didukung oleh hasil penelitian lain yang menyatakan bahwa orang tua dengan tingkat pendidikan yang rendah memiliki anak dengan masalah status gizi yang lebih tinggi dibandingkan orangtua dengan tingkat pendidikan tinggi [24]. Tingkat pendidikan dapat mempengaruhi kejadian stunting namun tidak terjadi secara signifikan, hal tersebut kemungkinan dipengaruhi oleh kemampuan setiap orangtua dalam mengakses informasi, karena terdapat orantua dengan tingkat pendidikan yang rendah namun memiliki sumber informasi yang baik dari pelayanan kesehatan terkait kebutuhan gizi anaknya.

Pelaksanaan peran keluarga secara optimal untuk mendukung peningkatan status gizi pada balita sehingga dapat menurunkan angka kejadian stunting. Peran keluarga dapat terlaksana dengan baik maka keluarga dapat melakukan peningkatan peran terutama dalam memberikan nutrisi pada anak usia balita. Pemebuhan nutrisi pada balita pun tidak lepas dari peran keluarga terutama keluarga yang mengasuh anak, maka pemenuhan nutrsi dapat dilakukan dengan pengajaran pada keluarga tentang kebutuhan nutrisi balita.

Berdasarkan hasil penelitian, intervensi yang dapat dilakukan perawat pada keluarga yang memiliki anak usia balita dengan masalah status gizi yaitu melakukan pengajaran: nutrisi balita dengan memberikan intrusi mengenai praktik-praktik nutrisi dan pemberian makan sesuai dengan perkembangan usianya [21]. Pertama memberikan informasi berupa materi-materi tertulis seperti booklet dan poster berisi informasi yang sesuai dengan kebutuhan pengetahuan tentang nutrisi untuk balita stunting. Kedua memberikan arahan pada orangtua/pengasuh balita untuk menawarkan makanan dengan porsi kecil namun dengan pemberian makan yang sering. Ketiga menawarkan makanan-makanan yang mengandung tinggi zat besi dan protein. Keempat memberikan arahan bagi orangtua/pengasuh memiliki waktu makan yang teratur dan makan sebagai sebuah 
keluarga seperti makan bersama. Kelima memberikan pilihan makanan yang sehat, menganjurkan makan sayuran mentah/dimasak, serta mengajak anak berpartisipasi dalam persiapan makan.

Berdasarkan hasil yang telah diperoleh maka peneliti mengungkapkan untuk mencapai status gizi yang optimal maka dapat meningkatkan peran keluarga baik peran formal maupun peran informal. Melibatkan peran keluarga dalam pemenuhan asupan gizi balita dapat membantu tenaga kesehatan dalam memberikan intervensi untuk balita yang mengalami masalah status gizi. Peningkatan peran keluarga dapat dilakukan dengan memberikan informasi dan pemahaman bagaimana keluarga harus melaksanakan perannya dalam pengasuhan anak terutama pada usia balita yang belum dapat bertindak secara otonomi

\section{Simpulan dan Saran}

Pelaksanaan peran keluarga di Kecamatan Arjasa Kabupaten Jember menunjukkan sebagian besar pelaksanaan peran keluarga dalam kategori sedang. Kejadian stunting pada Balita di Kecamatan Arjasa Kabupaten Jember menunjukkan sebagian besar anak usia balita mengalami masalah status gizi stunting. Pelaksanaan peran keluarga berhubungan dengan kejadian stunting di Kecamatan Arjasa Kabupaten Jember).

Pelibatan peran keluarga dalam pemenuhan gizi pada balita sehingga dapat meningkatkan status gizi balita. Pelibatan keluarga dapat dilakukan seperti membuat menu makanan yang sehat namun mudah didapat dan harganya relatif murah yaitu makanan yang bersumber dilingkungan sekitar keluarga. Peningkatan peran formal dan peran informal yang telah dilaksanakan pada keluarga yang mayoritas ibu dengan status tidak bekerja, maka ibu memiliki waktu luang dalam pengelolahan makanan yang memiliki nilai gizi tinggi.

\section{Daftar Pustaka}

[1] KDPDTT. Buku saku desa dalam penanganan stunting. Jakarta: Kementerian Desa, Pembangunan Daerah Tertinggal, dan Transmigrasi; 2017.

[2] WHO. Reducing stunting in children: equity considerations for achieving global nutrition target 2025. Switzerland: Departement of Nutrition for Health and Development; 2018.

[3] Steve. Global nutrition report: report reduction of malnutrition. Washington:
International Food Policy Research Institute; 2014.

[4] RISKESDAS. Penyakit yang ditularkan melalui udara. Jakarta: Badan Penelitian Dan Pengembangan Kesehatan Departemen Kesehatan Republik Indonesia; 2013.

[5] Dinas Kesehatan Jawa Timur. Profil jawal timur. Provinsi Jawa Timur; 2016.

[6] Kementerian Kesehatan RI. Hasil pemantauan status gizi (PSG) dan penjelasannya tahun 2016; 2016.

[7] Latri, R. A. D. Hubungan perilaku keluarga sadar gizi dengan kejadian stunting pada anak usia balita di kecamatan arjasa kabupaten jember. Tidak diterbitkan. Skripsi. Jember: Faultas Keperawatan Universitas Jember; 2018.

[8] Gurmu E, D Etana. Household structure and children's nutritional status in ethiopia. Genus [Internet]. 2013 [cited 20 September 2018];69(2):[pp. 113-130]. Available from: https://www.jstor.org/stable/genus.69.2.1 13 ? seq $=1$ \#page scan tab contents

[9] Novak, B. \& M. E. Muniagurria. The role of family structure on stunting (low height- for-age) in argentinian preschool children aged 2-5. International Journal of Sociology of the Family [Internet]. 2017 [cited 5 Desember 2018];40(2):[pp. 175-198]. Available from: https://www.jstor.org/stable/43488423?se $\mathrm{q}=1$ \#page_scan tab contents

[10] UNICEF Indonesia. Issue briefs: maternal and child nutrition. Jakarta; 2012.

[11] Kementerian Kesehatan RI. Situasi balita pendek. Jakarta; 2016.

[12] Carr, D. \& K. W. Springer. Advances in families and health research in the 21st century. Journal of Marriage and Family [Internet]. 2010 [cited 7 Desember 2018]; 72(3): [pp. 743-761]. Available from: https://onlinelibrary.wiley.com/doi/10.111 1/j.1741-3737.2010.00728.x

[13] Kementerian Kesehatan RI. Pedoman umum program inonesia sehat dengan pendekatan keluarga. Jakarta; 2016.

[14] Departemen Kesehatan RI. Pedoman strategi kie keluarga sadar gizi (KADARZI); 2007.

[15] Partini S, Sumantri T, Senssusiana. Peran perawat terhadap pencegahan gizi buruk pada balita di kabupaten klaten. Jurnal IImu Kesehatan Stikes Duta Gama Klaten [Internet]. 2016 [cited 15 Januari 2019]; 8(103): [pp. 1-18]. Available from: https://www.e- 
journal.stikesdutagama.ac.id/index.php/e -journal/issue/view/39

[16] Proverawati A, Wati EK. IImu gizi untuk perawat dan gizi kesehatan. Yulia Medika: Yogyakarta; 2011.

[17] Aridiyah, F.O, N. Rohmawati, \& M. Ririanty. Faktor-faktor yang mempengaruhi kejadian stunting pada anak balita di wilayah pedesaan dan perkotaan. e-Jurnal Pustaka Kesehatan [Internet]. 2015 [cited 18 Januari 2019];3(1):[pp. 163-170]. Available from: https://jurnal.unej.ac.id/index.php/JPK/art icle/view/2520

[18] Sukoco, N.E, J. Pambudi, \& M.H. Herawati. Hubungan status gizi anak balita dengan orang tua bekerja. Buletin Penelitian Sistem Kesehatan [Internet]. 2015 [cited 18 Januari 2019];18(4):[pp. 387-397. Available from: https://media.neliti.com/media/publication s/20965-ID-relationship-betweennutritional-status-of-children-under-fivewith-parents-who.pdf

[19] Sulastri, D. Faktor determinan kejadian stunting pada anak usia sekolah di kecamatan lubuk kilangan kota padang. Majalah Kedokteran Andalas [Internet]. 2012 [cited 18 Januari 2019];36(1):[pp.39-40]. Available from: http://jurnalmka.fk.unand.ac.id/index.php/ art/article/view/111
[20] Herdman T, Heather. NANDA international nursing diagnoses : definitions and classification 2018-2020. Edisi 11th. Jakarta: EGC; 2018

[21] Bulechek, Butcher, Dochterman, Wagner. Nursing interventions classification (NIC). Edisi 6th. Philadelpia: Elsevier; 2013.

[22] Soetjiningsih. Perkembangan anak dan permasalahannya dalam buku ajar ilmu perkembangan anak dan remaja. Jakarta: Sagungseto; 2012.

[23] Ibrahim, I.A. \& R. Faramita. Hubungan faktor sosial ekonomi keluarga dengan kejadian stunting anak usia 24-59 bulan di wilayah kerja puskesmas barombong kota makassar tahun 2014. Al-Sihah : Public Health Science Journal [Internet]. 2015 [cited 20 Januari 2019];7(1):[pp.6375]. Available from: http://journal.uinalauddin.ac.id/index.php/AlSihah/article/view/1978

[24] Khattak, U. K., S. P. Iqbal, \& H. Ghazanfar. The role of parents' literacy in malnutrition of children under the age of five years in a semi-urban community of pakistan: a case-control study. Cureus [Internet]. 2017 [cited 20 Januari 2019]; 9(6):[pp.1-10]. Available from: https://www.ncbi.nlm.nih.gov/pubmed/28 690950 